\title{
Calcium Transport across Plasma Membrane in Early Stages of Chronic Kidney Disease - Impact of Vitamin $\mathrm{D}_{3}$ Supplementation
}

Ingrid Lajdova* and Viera Spustova

Department of Clinical and Experimental Pharmacotherapy, Slovak Medical University, Slovak Republic

\begin{abstract}
Mini review summarizes the results of studies focused on elucidating pathophysiological mechanisms of altered intracellular calcium homeostasis in the peripheral blood mononuclear cells of patients with early stages of chronic kidney disease. The basic mechanisms of calcium entry as well as those of its removal are impaired by the disease. These disturbances cause an increase concentration of free cytosolic calcium which can result in a change of broad range of cellular processes and expression patterns of various signaling molecules. Vitamin $D_{3}$ supplementation is the standard treatment of frequent vitamin $D_{3}$ insufficiency or deficiency in these patients. It can be assumed that vitamin $\mathrm{D}_{3}$ through the pleiotropic effects may participate in modulation of intracellular calcium homeostasis. Vitamin $\mathrm{D}_{3}$ supplementation resulted in a reduction of cytosolic free calcium affecting some of the transport systems involved in cell calcium entry as well as calcium exit. Normalization of the cytosolic free calcium concentration can have a beneficial effect on intracellular signaling. The mechanisms for regulating and controlling intracellular calcium homeostasis in chronic kidney disease patients are currently still under investigation.
\end{abstract}

Keywords: Cytosolic calcium; Calcium transport; Vitamin D; Chronic kidney disease

Abbreviations: CKD: Chronic Kidney Disease, PBMCs: Peripheral Blood Mononuclear Cells, $\left[\mathrm{Ca}^{2+}\right]_{\mathrm{i}}$ : Free Cytosolic Calcium Concentration, $\mathrm{Ca}^{2+}$ : Calcium Cations, ROC: Receptor Operated Channel, VOC: Voltage Operated Channel, SMOC: Second Messenger Operated Channel, SOC: Store Operated Channel, CRAC channel: Calcium Release Activated Calcium Channel, PMCA: Plasma Membrane $\mathrm{Ca}_{2}+$-ATPase, ATP: Adenosine Triphosphate, 2APB: 2-Aminoethyl-Diphenylborate, $\mathrm{Tg}$ : Thapsigargin

\section{Review}

Calcium cations $\left(\mathrm{Ca}^{2+}\right)$ play an important role in the cellular signaling and in a number of physiological processes. The cell $\mathrm{Ca}^{2+}$ distribution is exactly regulated by transport systems which maintain low free cytosolic calcium concentration $\left(\left[\mathrm{Ca}^{2+}\right]_{\mathrm{i}}\right)(50-100 \mathrm{nmol} / \mathrm{l})$ in comparison with $\mathrm{Ca}^{2+}$ concentration in extracellular space (about 1.3 $\mathrm{mmol} / \mathrm{l}$ ). The plasma membrane possesses several types of channels which control the $\mathrm{Ca}^{2+}$ entry into the cells, and systems that extrude it. Calcium enters the cell by any of the general classes of channels, including voltage-operated channels (VOC), second messengeroperated channels (SMOC), store-operated channels (SOC) and receptor operated-channels (ROC). Calcium release from the cells is regelated principally by $\mathrm{Ca}^{2+}$ - ATPase, and $\mathrm{Na}^{+}$exchanger (Figure 1). Plasma membrane is responsible for the 10,000 -fold gradient of $\mathrm{Ca}^{2+}$ normally measured between the extracellular space and the cytoplasm. The very large gradient of $\mathrm{Ca}^{2+}$ across the plasma membrane not only ensures full availability of the cation, but it is also dynamically beneficial, since even minor changes in the $\mathrm{Ca}^{2+}$ permeability of the plasma membrane provides significant fluctuations in the $\left[\mathrm{Ca}^{+}\right]$i. Passing $\mathrm{Ca}^{2+}$ through the plasma membrane triggers a cascade of events that are vital for cellular activities. Calcium cation is an important ubiquitous messenger, controlling a broad range of cellular processes. It has a direct role in controlling the expression patterns of its signaling systems that are constantly being remodelled in both, health and disease.

Chronic kidney disease (CKD) is associated with a significant elevation in the $\left[\mathrm{Ca}^{+}\right] \mathrm{i}$ which is toxic to the cells and may be responsible for multiple organ dysfunction $[1,2]$. Knowledge of the relationship between $\mathrm{CKD}$ and cellular calcium homeostasis, as well as regulation mechanisms of calcium signaling especially in the early stages of the disease are missing.

Mini review summarizes the results of our studies focused on elucidating pathophysiological mechanisms of altered intracellular calcium homeostasis in the peripheral blood mononuclear cells (PBMCs) of CKD patients. Moreover, vitamin D deficiency or insufficiency is highly prevalent in CKD patients, and under current guidelines, the therapeutic strategies include supplementation of native vitamin D (ergocalciferol or cholecalciferol) [3]. The critical role of the vitamin $\mathrm{D}$ endocrine system in disease prevention extends beyond the classic regulation of calcium and phosphorus homeostasis and skeletal integrity, to its pleiotropic effects on extramineral metabolism $[4,5]$. Vitamin D is an important modulator of cellular proliferation, differentiation, inflammation and immunity. Vitamin D attenuates kidney injury by supressing fibrosis, inflammation, and apoptosis $[6,7]$. Therefore, the effect of vitamin D3 supplementation on the major mechanisms involved in maintaining cell calcium homeostasis was examined in patients with early stages of CKD.

\section{Free intracellular calcium}

Elevation of free cytosolic calcium concentration $\left(\left[\mathrm{Ca}^{2+}\right]_{\mathrm{i}}\right)$ is a highly versatile signal, that operates over a wide temporal range to regulate many different cellular processes. $\mathrm{Ca}^{2+}$ signals control many cellular functions, ranging from short-term responses such as contraction and secretion, to longer term regulation of cell growth and proliferation.

${ }^{*}$ Corresponding author: Dr. Ingrid Lajdova, PhD., Department of Clinical and Experimental Pharmacotherapy, Slovak Medical University, Limbova 12, 83303 Bratislava, Slovak Republic, Tel: + 421-2-59370139; Fax: + 421-2-59370598; E-mail: ingrid.lajdova@szu.sk

Received: November 09, 2015; Accepted: December 15, 2015; Published: December 29, 2015

Citation: Lajdova I, Spustova V (2015) Calcium Transport across Plasma Membrane in Early Stages of Chronic Kidney Disease - Impact of Vitamin D3 Supplementation. J Kidney 1: 108. doi:10.4172/2472-1220.1000108

Copyright: $\odot 2015$ Lajdova I, et al. This is an open-access article distributed under the terms of the Creative Commons Attribution License, which permits unrestricted use, distribution, and reproduction in any medium, provided the original author and source are credited. 
On the other hand, $\mathrm{Ca}^{2+}$ signal may induce apoptosis or less specific necrosis under special conditions. $\left[\mathrm{Ca}^{2+}\right]_{i}$ is controlled by mechanisms that regulate $\mathrm{Ca}^{2+}$ entry from the extracellular space and $\mathrm{Ca}^{2+}$ release from intracellular stores, and by the activity of ATP-dependent $\mathrm{Ca}^{2+}$ ATPases and antiporters that move $\mathrm{Ca}^{2+}$ back into stores or out of cells [8-10]. Previous studies on the metabolic profile of various cells have shown, that chronic renal failure already in early stages is associated with a significant elevation in $\left[\mathrm{Ca}^{2+}\right]_{i}$ (Figure 2) [11], which may be responsible for the multiple organ dysfunction in haemodialysed patients [12]. Most of the intracellular calcium is either sequestered in the endoplasmic reticulum and mitochondria, or bound to cytoplasmic proteins and other ligands. More and more evidence suggests that intracellular $\mathrm{Ca}^{2+}$ stores might be critical for some physiological processes [9].

For determination of intracellular $\mathrm{Ca}^{2+}$ stores, thapsigargin ( $\mathrm{Tg}$ ), the specific inhibitor of endoplasmic reticulum $\mathrm{Ca}^{2+}$ - ATPase, is used (Figure $3 \mathrm{~A})$. The effect of $\mathrm{Tg}$ in the absence of extracellular calcium strongly indicates that intracellular Tg sensitive calcium reserves in PBMCs of CKD patients (stage 2-3) are significantly higher in comparison with

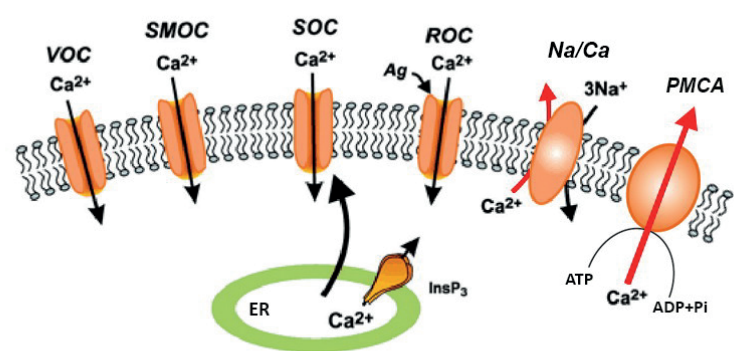

Figure 1: Basic mechanisms of calcium transport across plasma [9]. Calcium entry: ROC - receptor operated channel, VOC - voltage operated channel, SMOC -second messenger operated channel, SOC - store operated channel

Calcium removal: PMCA - plasma membrane $\mathrm{Ca}_{2}{ }^{+}-\mathrm{ATPase}, \mathrm{Na} / \mathrm{Ca}-\mathrm{Na}^{+} / \mathrm{Ca} 2$ exchanger

$\mathrm{Ag}$ - agonist, $\mathrm{IP}_{3}$ - inositol triphosphate, ATP - adenosine triphosphate, ADP adenosine diphosphate, $\mathrm{Pi}$ - inorganic phosphate, $\mathrm{ER}$ - endoplasmic reticulum

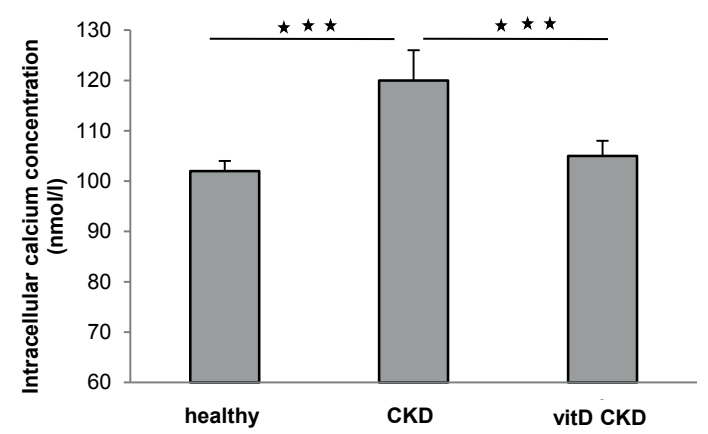

Figure 2: Measurements of free cytosolic calcium concentration [11]. Cytosolic $\mathrm{Ca}^{+}$measurements were performed by Fluo-3 fluorimetry in isolated PBMCs of healthy volunteers and CKD patients before and after vitamin $D_{3}$ supplementation $\left({ }^{* *} P<0.001\right)$. healthy volunteers (Figure $3 \mathrm{~B}$ ). Vitamin $\mathrm{D}_{3}$ supplementation returned the elevated $\left[\mathrm{Ca}^{2+}\right]_{i}$ in CKD patients to values comparable with healthy subjects (Figure 2), but did not affect intracellular calcium reserves (Figure 3B) $[11,13]$.

\section{Calcium entry}

Calcium release activated calcium channels: Calcium enters into the cells by calcium/cation channels. In nonexcitable cells, like PBMCs, the predominant $\mathrm{Ca}^{2+}$ entry pathway is the store-operated one, in which the emptying of intracellular $\mathrm{Ca}^{2+}$ stores activates the $\mathrm{Ca}^{2+}$ influx to the cell (Figure 1). This type of the channel is in PBMCs known as the calcium release activated calcium (CRAC) channel. The calcium entry through CRAC channels activates certain transcription factors which regulate the gene expression for cytokines responsible for immune responses [14,15]. Dysregulation of $\mathrm{Ca}^{2+}$ homeostasis involving the endoplasmatic reticulum and store-operated calcium channels has been manifested in neurodegenerative disorders, in patients with immunodeficiency, acute pancreatitis, polycystic kidney disease and cardiac hypertrophy [14-21].

In PBMCs of non-diabetic CKD patients, CRAC channels are activated indirectly by intracellular $\mathrm{Ca}^{2+}$ store depletion using $\mathrm{Tg}$, the specific inhibitor of endoplasmic reticulum $\mathrm{Ca}^{2+}$ - ATPase. When

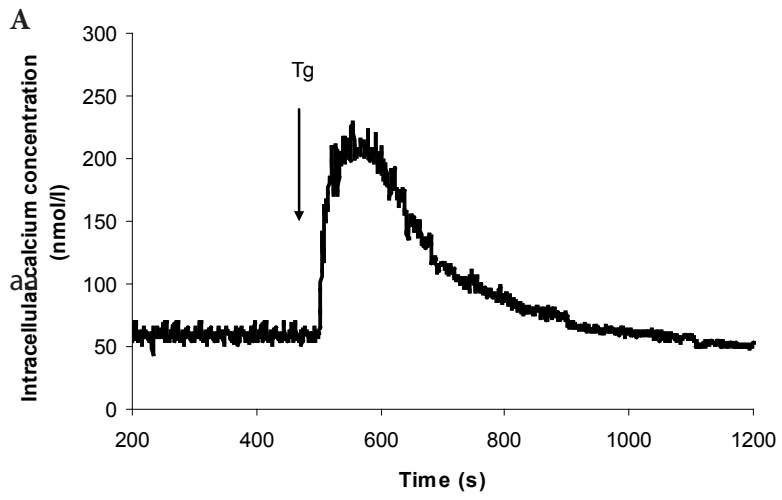

B

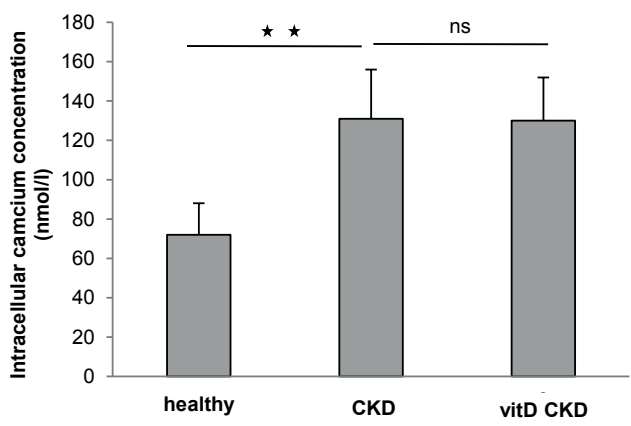

Figure 3: Determination of intracellular calcium concentration of Tg-sensitive stores [11].

(A) Typical effect of $\mathrm{Tg}$ (the specific inhibitor of endoplasmic reticulum $\mathrm{Ca}^{+}$ATPase) in a $\mathrm{Ca}^{+}$free physiological salt solution and in the presence of extracellular $\mathrm{Ca}^{+}{ }^{+}$chelator (EGTA, $\mathrm{pH}=7$ ).

(B) Comparison of intracellular calcium concentration of Tg-sensitive stores in PBMCs of healthy subjects, CKD patients at baseline and CKD patients after 12 -month vitamin $D_{3}$ supplementation $\left({ }^{* *} P<0.01\right)$ 
the reliable inhibitor of these channels 2-aminoethyl-diphenylborate (2APB) was applied during the sustained phase of Tg effect, it evoked a decrease in $\left[\mathrm{Ca}^{2+}\right]_{\mathrm{i}}$, which represents particularly the $\mathrm{Ca}^{2+}$ influx through CRAC channels (Figure 4A). In early stages of CKD, the calcium entry via CRAC channels was significantly increased when compared with healthy individuals. After the treatment with vitamin $\mathrm{D}_{3}$, the enhanced $\mathrm{Ca}^{2+}$ entry through these types of channels was significantly decreased (Figure 4B) [13].

L-type calcium channels: Many of previous studies have implicated L-type $\mathrm{Ca}^{2+}$ channels in $\mathrm{Ca}^{2+}$ influx during T-lymphocyte activation and proliferation [22]. Nonexcitable cells express $\mathrm{Ca}^{2+}$ channels that share common structural features with voltage-dependent $\mathrm{Ca}^{2+}$ channels of excitable cells, but are not solely gated by changes in membrane potential. However, Kotturi et al. presented both, molecular and pharmacological evidence for the presence of L-type $\mathrm{Ca}^{2+}$ channels in the plasma membrane of resting lymphocytes in 2003 [23].

Despite of this knowledge, in PBMCs of early-stage CKD patients, calcium influx via L-type $\mathrm{Ca}^{2+}$ channels was not increased in comparison with healthy subjects [11]. Stimulation PBMCs by $1,25(\mathrm{OH})_{2} \mathrm{D}_{3}$, an active metabolite of vitamin $\mathrm{D}$, does not induce calcium response through L-type calcium channels in healthy subjects [24]. In accordance with this finding, the calcium influx through L-type calcium channels was not observed after supplementation of vitamin $\mathrm{D}_{3}$.

P2X $_{7}$ receptors: At the present time, purinergic signaling is accepted as a crucial component of diseases and was found to mediate a vast array of biological processes [25-27]. Until today, seven subtypes

A)

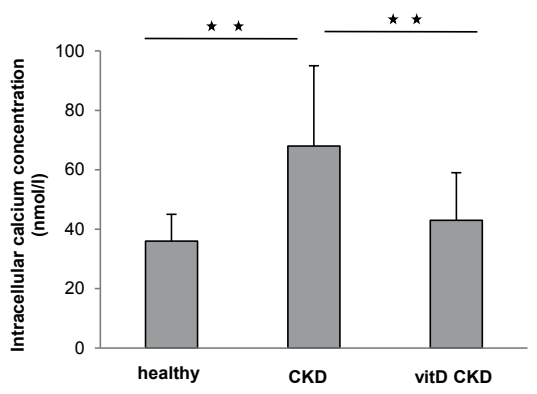

B)

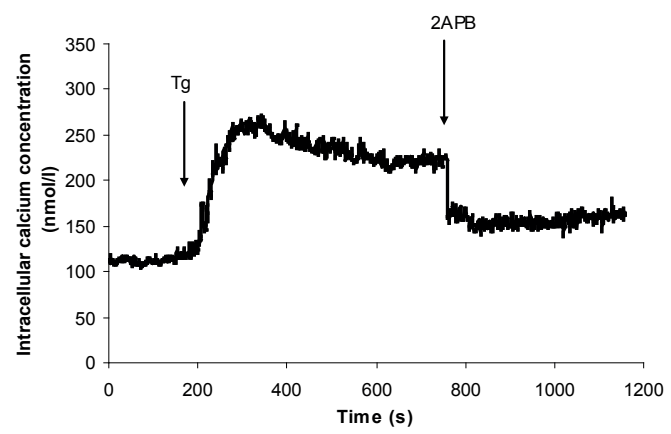

Figure 4: Calcium entry via calcium CRAC channels $[11,13]$.

Representative experiment where CRAC channels where activated indirectly by calcium releasing from intracellular reserves. The specific inhibitor of endoplasmic reticulum $\mathrm{Ca}^{2+}$-ATPase $(\mathrm{Tg})$ was applied before application of 2APB, an inhibitor of the CRAC channels.

(B) Comparison of the calcium entry through CRAC channels in PBMCs of healthy subjects, non-diabetic CKD patients and non-diabetic CKD patients after vitamin $D_{3}$ supplementation ( $\left.{ }^{* *} P<0.01\right)$. of $\mathrm{P} 2 \mathrm{X}$ receptors have been identified. $\mathrm{P}_{2} \mathrm{X}_{1}-\mathrm{P}_{2} \mathrm{X}_{6}$ are predominantly expressed by neurons and some excitable cells. The $\mathrm{P} 2 \mathrm{X}_{7}$ receptors are expressed primarily on cells of hemopoietic origin, where they participate in immune responses, cell proliferation, cell death, bone formation and resorption [25]. The $\mathrm{P} 2 \mathrm{X}_{7}$ receptor is a bifunctional purinoreceptor, that either opens a non-selective cation channel, or forms a large, cytolytic pore. ATP binding leads to opening of cation channel that permits $\mathrm{K}^{+}$efflux and both $\mathrm{Ca}^{2+}$ and $\mathrm{Na}^{+}$influx into the cells. This causes major disturbances of the ionic gradient across the plasma membrane that raises calcium influx into the cell, thus triggering several intracellular signaling cascades, including mediation of inflammatory responses and modulation of cell turnover. A key factor of $\mathrm{P} 2 \mathrm{X}_{7}$-dependent cytotoxicity is the massive intracellular $\mathrm{Ca}^{2+}$ increase triggered by its activation. It may result in membrane blebbing and cell death by apoptosis or necrosis. There is an increasing body of evidence implicating $\mathrm{P}_{2} \mathrm{X}_{7}$ receptor in various pathological conditions [28-31]. The most recent advances provide compelling evidence for $\mathrm{P} 2 \mathrm{X}$ receptors, playing a key role in regulating cell physiological and pathophysiological processes and are involved in the disrupted cell calcium homeostasis in CKD patients $[32,33]$.

In PBMCs of non-diabetic CKD patients $\mathrm{Ca}^{2+}$ entry via $\mathrm{P} 2 \mathrm{X}$ channels and pores has been increased and also the permeability of $\mathrm{P} 2 \mathrm{X}_{7}$ pores was higher, in comparison with healthy subjects. In addition, the function of $\mathrm{P} 2 \mathrm{X}_{7}$ channels and pores was altered [13,34]. It is known, that $1,25(\mathrm{OH})_{2} \mathrm{D}_{3}$, an active metabolite of vitamin $\mathrm{D}$, prevents $\mathrm{Ca}^{2+}$ increase through $\mathrm{P} 2 \mathrm{X}_{7}$ channels and reduces the plasma membrane permeability through $\mathrm{P}_{2} \mathrm{X}_{7}$ pores in human PBMCs of healthy subjects [24]. 1,25(OH) $\mathrm{D}_{3}$ can also up or downregulate the expression of several genes in many cell types. To our knowledge, the effect of $1,25(\mathrm{OH})_{2} \mathrm{D}_{3}$ on $\mathrm{P} 2 \mathrm{X}_{7}$ receptor expression has not been studied. Our study disclosed that vitamin $\mathrm{D}_{3}$ supplementation reduced $\mathrm{Ca}^{2+}$ influx through $\mathrm{P} 2 \mathrm{X}_{7}$ channels and affected their functionality. Moreover, the supplementation had no effect on permeability of $\mathrm{P} 2 \mathrm{X}_{7}$ pores, and the differences in responses to stimulation or inhibition were not found [13]. Different effects of vitamin $\mathrm{D}_{3}$ on $\mathrm{P} 2 \mathrm{X}_{7}$ channels and pores in $\mathrm{CKD}$ patients may have been made due to different sensitivity to these channels and pores. It is known, that various agonists and antagonists of $\mathrm{P} 2 \mathrm{X}_{7}$ receptors may have a distinct effect on the function of $\mathrm{P}_{2} \mathrm{X}_{7}$ channels and/or pores [35]. Not only the function, but also the expression of $\mathrm{P}_{2} \mathrm{X}_{7}$ receptors may be altered in some pathological conditions [26,36-38]. We found a 1.5 -fold increase in the expression of surface $\mathrm{P}_{2} \mathrm{X}_{7}$ receptors on PBMCs from non-diabetic CKD patients when compared to healthy subjects (Figure 5A) [39]. In our recent study, the flow cytometric measurement revealed, that vitamin $\mathrm{D}_{3}$ decreased the expression of $\mathrm{P} 2 \mathrm{X}_{7}$ receptors by 45\% (Figure 5B) [13]

\section{Calcium removal}

Plasma membrane $\mathrm{Ca}^{2+}$ ATPase: The plasma membrane possesses two systems that extrude $\mathrm{Ca}^{2+}$ : a high-affinity, low-capacity $\mathrm{Ca}^{2+}$ - ATPase, and a lower affinity, large-capacity $\mathrm{Na}^{+} / \mathrm{Ca}^{2+}$ exchanger which is particularly active in excitable cells. The plasma membrane $\mathrm{Ca}^{2+}$ - ATPase (PMCA) is critical for the maintenance of resting $\left[\mathrm{Ca}^{2+}\right]$ in non-excitable cells and may be the last gatekeeper for the control of low $\left[\mathrm{Ca}^{2+}\right]_{i}$.

PMCA activity of non-diabetic CKD patients is reduced by $34 \%$ against healthy subjects [40]. This finding is consistent with other studies and points out that the PMCA activity decreases with kidney disease progression [41]. The decline in PMCA activity may be caused by numerous factors, such as calmodulin deficiency, an activity of other endogenous protein regulators, and inhibition of mitochondrial or 


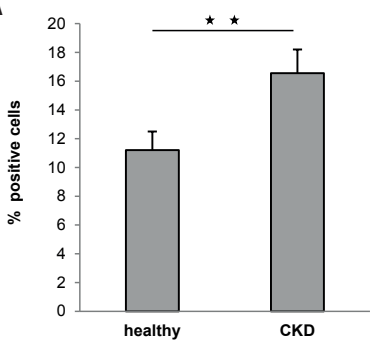

B

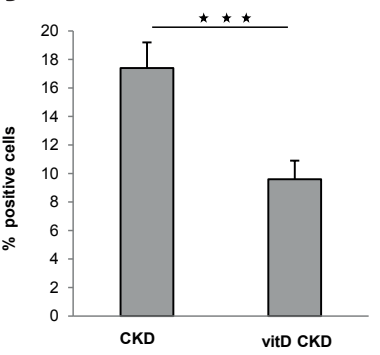

Figure 5. The expression of cell surface P2X7 receptors [13,34]. The expression of $\mathrm{P}_{2} \mathrm{X}_{7}$ receptors was measured by flow cytometry using primary antibody for the extracellular domain of the $\mathrm{P}_{2} \mathrm{X}_{7}$ receptor (anti-P2X (extracellular) antibody)

(A) Expression of $\mathrm{P} 2 \mathrm{X}_{7}$ receptors on PBMCs of healthy subjects and early stages non-diabetic CKD patients $\left({ }^{* *} P<0.01\right)$.

(B) Expression of surface P2X receptors before and after 6-month vitamin D3 supplementation $\left({ }^{* * *} \mathrm{P}<0.001\right)$.

glycolytic metabolism [42]. The $\mathrm{Ca}^{2+}$ influx through CRAC channels is also an important regulator of PMCA activity, and an altered communication between them may be another cause of PMCA malfunction $[43,44]$. Several experimental studies have observed direct and/or indirect effects of $1,25(\mathrm{OH})_{2} \mathrm{D}_{3}$ and/or $24,25(\mathrm{OH})_{2} \mathrm{D}_{3}$ on activity and expression of PMCA in different cells, but the effects of $25(\mathrm{OH})$ $\mathrm{D}_{3}$ itself, have not been studied. The studies targeting at the effects of native vitamin $\mathrm{D}_{3}$ supplementation on cell calcium homeostasis in patients with early stages of CKD are missing. In our study the impact of 6 month vitamin $\mathrm{D}_{3}$ (cholecalciferol) supplementation on the PMCA activity was investigated [40]. After the treatment, no changes in PMCA activity were detected. However, the concentration of plasma membrane proteins was increased by $47 \%$. Therefore, the possibility of increased expression of PMCA cannot be excluded $[13,40]$.

\section{Conclusions}

Our studies contribute to elucidation of pathophysiological mechanisms of altered intracellular calcium homeostasis in PBMCs of patients with CKD. Already in early stages of CKD, cytosolic free calcium concentration and calcium concentration of intracellular stores are significantly increased mainly due to increased activity of CRAC channels and $\mathrm{P} 2 \mathrm{X}_{7}$ receptors activation and expression. This disturbed calcium balance can activate aberrant inflammatory and vascular pathways participating in renal injury, which may contribute to progression of renal disease $[27,45]$. Pharmacological blocade of $\mathrm{P} 2 \mathrm{X}_{7}$ receptor protect agonist antibody-mediated glomerular inflammation and hypertensive renal injury in rodent [45]. Renoprotection is associated with reduced numbers of renal macrophages and has been atributed to direct anti-inflammatory effect of $\mathrm{P} 2 \mathrm{X}_{7}$ antagonism. Similarly, pharmacological suppression of CRAC channel activity reduces pro-inflammatory cytokine expression [46]. Thus, P2X receptor and CRAC channel blocade may have broad therapeutic value not only in renal disease. Vitamin $\mathrm{D}_{3}$ supplementation in $\mathrm{CKD}$ patients causes reduction in calcium influx through CRAC channels and $\mathrm{P}_{2} \mathrm{X}_{7}$ receptors and downregulation of $\mathrm{P} 2 \mathrm{X}_{7}$ receptors expression. These effects of vitamin $\mathrm{D}_{3}$ may be involved in anti-inflammatory and immunoregulatory effects of vitamin $\mathrm{D}_{3}$ in CKD patients and can contribute to its renoprotective effect in general.

\section{References}

1. Massry SG, Fadda GZ (1993) Chronic renal failure is a state of cellular calcium toxicity. Am J Kidney Dis 21: 81-86.

2. Ori Y, Korzets A, Malachi T, Gafter U, Breitbart H (1999) Impaired lymphocyte calcium metabolism in end-stage renal disease: enhanced influx, decreased efflux, and reduced response to mitogen. J Lab Clin Med 133: 391-400.

3. National Kidney Foundation (2003) K/DOQI clinical practice guidelines for bone metabolism and disease in chronic kidney disease. Am J Kidney Dis 42: S1-201.

4. Dusso A, González EA, Martin KJ (2011) Vitamin D in chronic kidney disease. Best Pract Res Clin Endocrinol Metab 25: 647-655.

5. Chowdhury R, Kunutsor S, Vitezova A, Oliver-Williams C, Chowdhury S, et al. (2014) Vitamin D and risk of cause specific death: systematic review and meta-analysis of observational cohort and randomised intervention studies. BMJ 348: g1903.

6. Tang J (2009) Vitamin D and its role in chronic kidney disease. Nephrol Rounds 7: $1-6$.

7. Liu WC, Zheng CM, Lu CL, Lin YF, Shyu JF, et al. (2015) Vitamin D and immune function in chronic kidney disease. Clin Chim Acta 450: 135-144.

8. Berridge MJ (1997) Elementary and global aspects of calcium signalling. J Exp Biol 200: 315-319.

9. Parekh AB, Putney JW Jr (2005) Store-operated calcium channels. Physiol Rev 85: 757-810.

10. Lewis RS (2001) Calcium signaling mechanisms in T lymphocytes. Annu Rev Immunol 19: 497-521.

11. Lajdova I, Spustova V, Oksa A, Chorvatova A, Chorvat D Jr, et al. (2009) Intracellular calcium homeostasis in patients with early stages of chronic kidney disease: effects of vitamin D3 supplementation. Nephrol Dial Transplant 24 3376-3381.

12. Massry SG, Smogorzewski M (1997) Role of elevated cytosolic calcium in the pathogenesis of complications in diabetes mellitus. Miner Electrolyte Metab 23: 253-260.

13. Lajdova I, Spustova V, Oksa A, Kaderjakova Z, Chorvat D Jr, et al. (2015) The Impact of Vitamin D3 Supplementation on Mechanisms of Cell Calcium Signaling in Chronic Kidney Disease. Biomed Res Int 2015: 807-673.

14. Partiseti M, Le Deist F, Hivroz C, Fischer A, Korn H, et al. (1994) The calcium current activated by $T$ cell receptor and store depletion in human lymphocytes is absent in a primary immunodeficiency. J Biol Chem 269: 32327-32335.

15. Feske S, Picard C, Fischer A (2010) Immunodeficiency due to mutations in ORAI1 and STIM1. Clin Immunol 135: 169-182.

16. Mattson MP, Chan SL (2003) Neuronal and glial calcium signaling in Alzheimer's disease. Cell Calcium 34: 385-397.

17. Raraty M, Ward J, Erdemli G, Vaillant C, Neoptolemos JP, et al. (2000) Calciumdependent enzyme activation and vacuole formation in the apical granular region of pancreatic acinar cells. Proc Natl Acad Sci U S A 97: 13126-13131.

18. Somlo S, Ehrlich B (2001) Human disease: calcium signaling in polycystic kidney disease. Curr Biol 11: R356-360.

19. Luo X, Hojayev B, Jiang N, Wang ZV, Tandan S, et al. (2012) STIM1-dependent store-operated $\mathrm{Ca} \hat{A}^{2} \hat{a}^{\circ}$ entry is required for pathological cardiac hypertrophy. $J$ Mol Cell Cardiol 52: 136-147.

20. McCarl CA, Picard C, Khalil S, Kawasaki T, Röther J, et al. (2009) ORAl1 deficiency and lack of store-operated $\mathrm{Ca} 2+$ entry cause immunodeficiency, myopathy, and ectodermal dysplasia. J Allergy Clin Immunol 124: 1311-1318.

21. Picard C, McCarl CA, Papolos A, Khalil S, Lüthy K, et al. (2009) STIM1 mutation associated with a syndrome of immunodeficiency and autoimmunity. $\mathrm{N}$ Engl J Med 360: 1971-1980.

22. Birx DL, Berger M, Fleisher TA (1984) The interference of T cell activation by calcium channel blocking agents. J Immunol 133: 2904-2909.

23. Kotturi MF, Carlow DA, Lee JC, Ziltener HJ, Jefferies WA (2003) Identification and functional characterization of voltage-dependent calcium channels in $T$ lymphocytes. J Biol Chem 278: 46949-46960.

24. Lajdova I, Chorvat D Jr, Chorvatova A (2008) Rapid effects of 1alpha,25(OH)2D3 in resting human peripheral blood mononuclear cells. Eur J Pharmacol 586: 14-23.

25. Ralevic V, Burnstock G (1998) Receptors for purines and pyrimidines. 
Citation: Lajdova I, Spustova V (2015) Calcium Transport across Plasma Membrane in Early Stages of Chronic Kidney Disease - Impact of Vitamin D3 Supplementation. J Kidney 1: 108. doi:10.4172/2472-1220.1000108

Page 5 of 5

Pharmacol Rev 50: 413-492.

26. Gu BJ, Zhang WY, Bendall LJ, Chessell IP, Buell GN, et al. (2000) Expression of P2X(7) purinoceptors on human lymphocytes and monocytes: evidence fo nonfunctional P2X(7) receptors. Am J Physiol Cell Physiol 279: C1189-1197.

27. Howarth AR, Conway BR1, Bailey MA2 (2015) Vascular and inflammatory actions of P2X receptors in renal injury. Auton Neurosci 191: 135-140.

28. Di Virgilio F, Solini A (2002) P2 receptors: new potential players in atherosclerosis. Br J Pharmacol 135: 831-842.

29. Jørgensen NR, Henriksen Z, Sørensen OH, Eriksen EF, Civitelli R, et al. (2002) Intercellular calcium signaling occurs between human osteoblasts and osteoclasts and requires activation of osteoclast P2X7 receptors. J Biol Chem 277: 7574-7580.

30. North RA (2002) Molecular physiology of P2X receptors. Physiol Rev 82: $1013-$ 1067.

31. Vonend O, Turner CM, Chan CM, Loesch A, Dell'Anna GC, et al. (2004) Glomerular expression of the ATP-sensitive P2X receptor in diabetic and hypertensive rat models. Kidney Int 66: 157-166.

32. Birch RE, Schwiebert EM, Peppiatt-Wildman CM, Wildman SS (2013) Emerging key roles for P2X receptors in the kidney. Front Physiol 4: 262.

33. Arulkumaran N, Turner CM, Sixma ML, Singer M, Unwin R, et al. (2013) Purinergic signaling in inflammatory renal disease. Front Physiol 4: 194.

34. Lajdova I, Oksa A, Chorvat D Jr, Topor P, Spustova V (2012) Purinergic $\mathrm{P} 2 \mathrm{X} 7$ receptors participate in disturbed intracellular calcium homeostasis in peripheral blood mononuclear cells of patients with chronic kidney disease. Kidney Blood Press Res 35: 48-57.

35. Ferreira LGB, Reis RAM, Alves LA, Faria RX (2012) Intracellular signaling pathways integrating the pore associated with P2X7R receptor with other large pores.in Patch ClampTechnique. FS Kaneez, Ed., 37-54, Tech Open Access Publishing, Vienna, Austria.

36. Franco-Martínez S, Niño-Moreno P, Bernal-Silva S, Baranda L, Rocha-Meza M, et al. (2006) Expression and function of the purinergic receptor P2X7 in patients with pulmonary tuberculosis. Clin Exp Immunol 146: 253-261.
37. García-Hernández MH, Portales-Cervantes L, Cortez-Espinosa N, VargasMorales JM, Fritche Salazar JF, et al. (2011) Expression and function of P2X(7) receptor and CD39/Entpd1 in patients with type 2 diabetes and their association with biochemical parameters. Cell Immunol 269: 135-143.

38. Madec S, Rossi C, Chiarugi M, Santini E, Salvati A, et al. (2011) Adipocyte $\mathrm{P} 2 \mathrm{X7}$ receptors expression: a role in modulating inflammatory response in subjects with metabolic syndrome? Atherosclerosis 219: 552-558.

39. Kaderjakova Z, Lajdova I, Horvathova M, Morvova M, Sikurova L (2012) Effects of chronic kidney disease on blood cells membrane properties. Bioelectrochem 87: 226-229.

40. Morvova jr. M, Lajdova I, Spustova V, Zvarik M, Sikurova L (2014) The effect of vitamin D3 supplementation on intracellular calcium and plasma membrane calcium ATPase activity in early stages of chronic kidney disease. Physiol Res 63: S593-S599.

41. Gafter U, Malachi T, Barak H, Djaldetti M, Levi J (1989) Red blood cell calcium homeostasis in patients with end-stage renal disease. J Lab Clin Med 114: 222-231.

42. Holton ML, Wang W, Emerson M, Neyses L, Armesilla AL (2010) Plasma membrane calcium ATPase proteins as novel regulators of signal transduction pathways. World J Biol Chem 1: 201-208.

43. Bautista DM, Lewis RS (2004) Modulation of plasma membrane calciumATPase activity by local calcium microdomains near CRAC channels in human T cells. J Physiol 556: 805-817.

44. Baryshnikov SG, Pulina MV, Zulian A, Linde CI, Golovina VA (2009) Orai1, a critical component of store-operated $\mathrm{Ca} 2+$ entry, is functionally associated with $\mathrm{Na}+/ \mathrm{Ca} 2+$ exchange and plasma membrane $\mathrm{Ca} 2+$ pump in proliferating human arterial myocytes. Am J Physiol Cel Physiol 297: C1103-C1112.

45. Menzies RI, Howarth AR, Unwin RJ, et al. (2015) Inhibition of the purinergic $\mathrm{P} 2 \mathrm{X} 7$ receptor improves renal perfusion in angiotensin-II-infused rats. Kidney Int 88: 1079-1087.

46. Grundy S, Kaur M, Plumb J, Reynolds S, Hall S, et al. (2014) CRAC channel inhibition produces greater anti-inflammatory effects than glucocorticoids in CD8 cells from COPD patients. Clin Sci (Lond) 126: 223-232. 